\title{
PENINGKATKAN KINERJA GURU DAN PRESTASI SISWA MELALUI PENERAPAN GAYA KEPEMIMPINAN OPEN DAN SITUASIONAL DI MA DARUL MA'ARIF NUMBAY PADA MASA PANDEMIC COVID 19
}

\author{
IRAWATY \\ MA Darul Ma'arif Numbay Jayapura \\ Email : irawatykuncoro@gmail.com
}

\begin{abstract}
ABSTRAK
Pandemi covid 19 sangat mempengaruhi segala bidang termasuk pengelolaan suatu sekolah/madrasah dipengaruhi oleh gaya kepemimpinan kepala madrasah. Gaya kepemimpinan merupakan suatu cara yang dimiliki oleh kepala madrasah dalam melaksanakan kepemimpinan khusus di MA Darul Ma'arif Numbay. Tujuan penelitian ini adalah mengambarkan gaya kepemimpinan kepala madrasah di MA Darul Ma'arif Numbay dalam meningkatkan kinerja dan prestasi siswa di masa pandemic covid 19. Metode penelitian kualitatif. Teknik analisis data menggunakan data deskriptif kualitatif. Hasil penelitian menunjukkan bahwa gaya kepemimpinan yang digunakan kepala madrasah dalam menerapkan gaya kepemimpinan open dan situasional di MA Darul Ma'arif Numbay pada masa pandemic covid 19 telah berjalan dan hasilnya sudah terlihat dan dapat dirasakan oleh warga madrasah termasuk peserta didik dengan meningkatnya kinerja guru dan adanya prestasi siswa bidang akademik kompetensi sains madrasah di bidang matematika dan fisika tahun 2021.
\end{abstract}

Kata Kunci : Gaya kepemimpinan open dan situasional, kinerja guru, prestasi siswa

\section{ABSTRACT}

The COVID-19 pandemic has greatly affected all fields, including the management of a school/madrasah, which is influenced by the leadership style of the principal. Leadership style is a method that is owned by the head of the madrasa in carrying out special leadership at MA Darul Ma'arif Numbay. The purpose of this study is to describe the leadership style of the madrasa principal at MA Darul Ma'arif Numbay in improving student performance and achievement during the covid 19 pandemic. Qualitative research method. The data analysis technique used qualitative descriptive data. The results showed that the leadership style used by the madrasah principal in applying the open and situational leadership style at MA Darul Ma'arif Numbay during the COVID-19 pandemic has been running and the results have been seen and can be felt by madrasa residents including students with increased teacher performance and the existence of student achievement in the academic field of madrasa science competence in the fields of mathematics and physics in 2021.

Keywords: open and situational leadership style, teacher performance, student achievement

\section{PENDAHULUAN}

Munculnya pandemi global yaitu virus corona atau yang disebut dengan Covid-19 memberikan dampak yang luar biasa terhadap aktifitas kehidupan masyarakat di dunia. Indonesia salah satu negara yang ikut terkena dampak penyebaran Covid-19, sehingga menuntut perubahan dalam melakukan aktifitas sehari-hari di berbagai bidang. Sistem penyebaran Covid-19 yang begitu luar biasa dahsyatnya menuntut semua elemen untuk melakukan upaya pencegahan atau memutus rantai penyebaran Covid-19 yang lebih besar.

Hal ini tentunya berdampak pada pelaksanaan sistem pembelajaran yang berubah dari tatap muka menjadi sistem pembelajaran daring/online. Perubahan terjadi hampir di seluruh lembaga pendidikan di Indonesia, termasuk di MA Darul Ma'arif Numbay.

Mengingat beban yang diemban Madrasah begitu berat,di masa pandemic covid 19 maka Madrasah harus dikelola secara professional agar dihasilkan tamatan yang sesuai dengan harapan pemerintah. Realitanya, banyak lembaga pendidikan yang dapat tumbuh dan berkembang menjadi lebih baik dan ada pula yang mengalami kemendekan dan bahkan tinggal 
menunggu kehancurannya di masa pandemik. Adapun salah satu faktor penyebabnya adalah terletak pada kompetensi dan gaya kepemimpinan kepala madrasah dalam mengelola madrasah. Hal ini sesuai dengan hasil penelitian (Yunidar, 2014) yang mengatakan 'Madrasah dapat meningkatkan motivasi guru dengan tindakan preventif agar guru tidak melakukan penyimpangan dan lebih berhati-hati dalam melaksanakan pekerjaannya'. Apabila seorang kepala madrasah tidak bisa mengatur, mempengaruhi, mengajak anggotanya untuk meraih tujuan pendidikan, gagal memanfaatkan peluang yang ada, dan cenderung menerapkan gaya kepemimpinan yang sekedar melaksanakan tugas rutin, maka jangan diharapkan kualitas pendidikan akan mengalami peningkatan. Sebaliknya, jika seorang kepala madrasah tersebut memiliki potensi yang cukup baik, maka kepala madrasah akan cenderung untuk terus meningkatkan organisasi pendidikan di lembaga yang dipimpinnya. Sehingga dengan sendirinya kualitas pendidikan ikut meningkat. MA Darul Ma'arif Numbay merupakan sekolah yang berada di tengah kota Abepura. Menyadari akan keadaan tersebut, MA Darul Ma'arif Numbay memiliki harapan besar untuk dapat mengembangkan madrasah dan mencapai prestasi yang maksimal dimasa pandemik covid 19. Namun harapan besar tersebut nampaknya terkendala oleh banyaknya masalah besar yang harus segera dicarikan solusi. Dari hasil initial evaluation (evaluasi awal) ditemukan kondisi awal MA Darul Ma'arif Numbay banyak masalah yang terjadi di masa pandemik covid 19 antara lain guru di MA Darul Ma'arif Numbay mempunyai etos kerjanya rendah, ketertiban dan kedisiplinan dalam bekerja rendah, perilaku kerja dan profesionalitas guru dalam bekerja rendah, bahkan orientasi kerja juga rendah, kekeluargaan/kebersamaan kurang.

Penulis menduga munculnya masalah di atas disebabkan oleh gaya kepemimpinan kepala madrasah tidak efektif jika diterapkan di masa pandemik covid 19 dan hal ini dapat berakibat sangat fatal. Semua komponen yang meliputi Sarpras, guru dan karyawan di madrasah serta masyarakat tidak bermanfaat bagi pencapaian tujuan madrasah terutama untuk meningkatkan prestasi belajar peserta didik.

Berdasarkan fakta-fakta yang ditemukan dan uraian di atas, perlu diupayakan pemecahannya. Salah satu upaya yang dilakukan adalah menerapkan gaya kepemimpinan open dan situasional sebagai upaya pengelolaan Madrasah Aliyah Darul Ma'arif Numbay untuk meningkatkan kinerja guru dan prestasi siswa di masa pandemic covid 19.

\section{METODE PENELITIAN}

Pada penelitian tentang gaya kepemimpinan penulis sebagai kepala madrasah di MA Darul Ma'arif Numbay dalam meningkatkan kinerja guru dan prestasi siswa. Penulis menggunakan metode penelitian deskriptif kualitatif (Cropley, 2019);(Palmer \& Bolderston, 2006). Data di ambil dari hasil angket yang di edarkan ke pada 15 guru MA Darul Ma'arif Numbay untuk menghitung presentase peningkatan kinerja guru. Penulis menggunakan teknik analisis data dengan menggunakan konsep dari Miles dan Huberman yang meliputi reduksi data, penyajian data dan penarikan kesimpulan (Mardawani, 2020).

\section{HASIL DAN PEMBAHASAN}

\section{Hasil}

Berdasarkan hasil analisis data diketahui bahwa peranan kepala madrasah sangat dibutuhkan di madrasah terutama di masa pandemic covid 19, sebab kepala madrasah merupakan pucuk pimpinan yang bertanggungjawab untuk menentukan arah perkembangan sekolah agar dapat menjamin mutu pendidikan (Mbogo, 2020). Dalam hal ini, yang dilakukan oleh penulis sebagai kepala madrasah dalam menjalankan perannya sebagai seorang pemimpin dengan menggunakan gaya kepemimpinan open dan situasional yang diuraikan pada grafik 1 . 


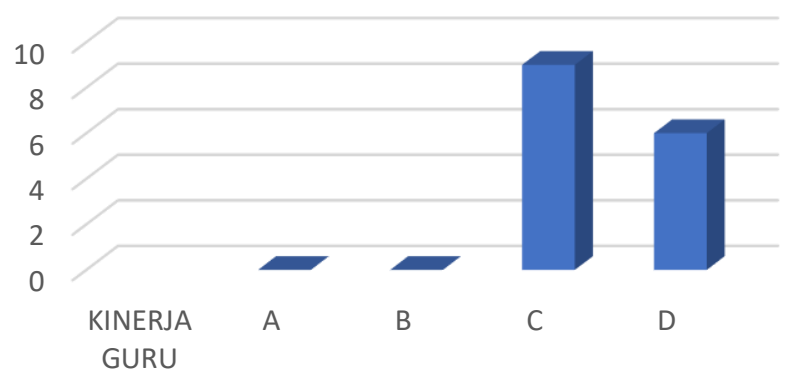

Gambar 1. Grafik Hasil rekapitulasi data angket kinerja guru setelah di terapkan gaya kepemimpinan open dan situasional di MA Darul Ma'arif Numbay di masa pandemic covid 19

Pada grafik 1 terlihat bahwa adanya peningkatan kinerja guru terutama dalam implementasi gaya telling, gaya selling, gaya participation, dan gaya delegating. Hal ini diuraikan pada tabel 1 .

Tabel 1 Implementasi Gaya Kepemimpinan open dan Situsional Di MA Darul Ma'arif Numbay

\begin{tabular}{|c|c|c|}
\hline $\begin{array}{l}\text { Gaya Telling } \\
\text { (Memberitahukan) }\end{array}$ & $\begin{array}{l}\text { Implementasi Gaya Telling } \\
\text { (Memberitahukan) }\end{array}$ & Dokumentasi \\
\hline $\begin{array}{l}\text { Kepala Madrasah dalam } \\
\text { memberikan pekerjaan } \\
\text { kepada guru selalu } \\
\text { memberikan perintah, dan } \\
\text { tidak bersifat memaksa. } \\
\text { Kepala sekolah selalu } \\
\text { memberikan pengarahan } \\
\text { terlebih dahulu sebelum } \\
\text { melaksasnakan pekerjaan }\end{array}$ & $\begin{array}{l}\text { Penulis selaku pimpinan } \\
\text { memberikan arahan atau tugas } \\
\text { kepada bawahannya untuk } \\
\text { mengerjakan suatu tugas dan } \\
\text { disampaikan dengan jelas dan } \\
\text { detail sampai pada isi pokok } \\
\text { persoalan yang akan } \\
\text { dibicarakan dalam agenda } \\
\text { rapat bersama dengan orang } \\
\text { tua siswa. }\end{array}$ & $\begin{array}{l}\text { Rapat Dengan orang tua } \\
\text { siswa dalam pelaksanaan } \\
\text { Ujian }\end{array}$ \\
\hline \multicolumn{3}{|l|}{ Gaya Selling (Menjajakan) } \\
\hline $\begin{array}{l}\text { Terdapat aturan yang jelas } \\
\text { yang dibuat oleh kepala } \\
\text { madrasah dalam } \\
\text { memberikan tugas. } \\
\text { Kepala madrasah } \\
\text { memberikan kesempatan } \\
\text { kepada guru untuk } \\
\text { berpendapat. } \\
\text { Kepala madrasah dalam } \\
\text { menjalankan tugasnya } \\
\text { berlaku demokrasi. } \\
\text { Kepala madrasah dapat } \\
\text { menerima saran dari guru, } \\
\text { Kepala sekolah selalu } \\
\text { memberikan motivasi } \\
\text { kepada bawahan dalam } \\
\text { menyelesaikan pekerjaan } \\
\text { Kepala madrasah } \\
\text { memberikan pujian dan } \\
\text { insentif kepada guru bila }\end{array}$ & $\begin{array}{l}\text { Penulis selalu memberikan } \\
\text { kesempatan kepada guru } \\
\text { untuk } \\
\text { ide/pendapat dalam rapat, } \\
\text { memimpin rapat berlaku } \\
\text { demokratis } \\
\text { memaksakan kehendaknya, } \\
\text { selain itu penulis memberikan } \\
\text { motivasi kepada guru untuk } \\
\text { dapat meningkatkan } \\
\text { kinerjanya dengan cara } \\
\text { memberikan penghargaan }\end{array}$ & Rapat mereviu dokumen \\
\hline
\end{tabular}




\begin{tabular}{|c|c|c|}
\hline $\begin{array}{l}\text { menyelesaikan pekerjaan } \\
\text { dengan baik } \\
\text { Participatin }\end{array}$ & & \\
\hline \multicolumn{3}{|c|}{ Gaya Participating (Mengikutsertakan) } \\
\hline $\begin{array}{l}\text { Kepala madrasah mampu } \\
\text { membuat keputusan secara } \\
\text { tepat dalam menyelesaikan } \\
\text { masalah dan keputusan yang } \\
\text { diambil oleh kepala } \\
\text { madrasah dapat diterima } \\
\text { oleh semua pihak. } \\
\text { Kepala madrasah selama ini } \\
\text { aktif dalam berbagai } \\
\text { kegiatan yangdilakukan } \\
\text { oleh warga masyarakat }\end{array}$ & $\begin{array}{lr}\text { Kepala madrasah } \\
\text { beserta para guru } \\
\text { mengikuti kerja } \text { bakti } \\
\text { yang diadakan oleh } \\
\text { warga masyarakat. }\end{array}$ & $\begin{array}{l}\text { Foto kegiatan bersih bersih } \\
\text { yang dilakukan secara bersama } \\
\text { oleh warga masyarakat, apart } \\
\text { pemerintah, dan warga sekolah }\end{array}$ \\
\hline \multicolumn{3}{|c|}{ Gaya Delegating (Mendelegasikan) } \\
\hline $\begin{array}{l}\text { Kepala madrasah memantau } \\
\text { memantau pekerjaan guru } \\
\text { Kepala madrasah } \\
\text { memberikan tanggung } \\
\text { jawab penuh kepada guru } \\
\text { dalam menyelesaikan } \\
\text { pekerjaan. }\end{array}$ & $\begin{array}{lr}\text { Penulis memberikan } \\
\text { tugas kepada } & \text { seorang } \\
\text { guru sekaligus } & \text { sebagai } \\
\text { wakil } & \text { kurikulum } \\
\text { mengikuti } & \text { diklat } \\
\text { penilaian dari } & \text { BDK } \\
\text { Papua. } & \end{array}$ & Guru mengikuti dilkat \\
\hline
\end{tabular}

Pada prestasi siwa terlihat juga menunjukkkan adanya prestasi walaupun tidak mengalami peningkatan namun di masa pandemic prestasi siswa tetap ada. Hal ini ditunjukkan pada tabel 2.

Tabel 2. Prestasi siswa MA Darul Ma'arif Numbay di masa Pandemic covid 19 Pembahasan

\begin{tabular}{|l|l|}
\hline Tahun & Prestasi \\
\hline 2020 & $\begin{array}{l}\text { Juara 2 Kompetensi Sains Madrasah Online bidang } \\
\text { fisika Tingkat Propinsi Papua }\end{array}$ \\
\hline 2021 & $\begin{array}{l}\text { Juara 1 Kompetensi Sains Madrasah bidang Fisika } \\
\text { Tingkat Kota Jayapura } \\
\text { Juara 3 Kompetensi Sains Madarasah bidang } \\
\text { Matematika Tingkat Kota Jayapura } \\
\text { Jiara 3 Kompetensi Sains Madrasah bidang fisika } \\
\text { Tingkat Propinsi Papua }\end{array}$ \\
\hline
\end{tabular}

Hasil penelitian menunjukan bahwa penulis sebagai kepala madrasah telah melaksanakan berbagai tindakan kepemimpinan dalam upaya peningkatan kinerja guru dan prestasi siswa dengan menggunakan gaya kepemimpinan open dan situasional di masa pandemic covid 19. Dalam hal ini, penulis sebagai kepala madrasah telah berupaya menerapkan prinsip kepemimpinan sekolah sebagaimana disebutkan oleh (Sagala, 2018) bahwa proses kepemimpinan adalah seseorang yang mempunyai wewenang, pengikut dan memiliki kemampuan mempengaruhi dan meyakinkan orang lain untuk melakukan sesuatu dengan penuh tanggung jawab serta membuat keputusan untuk mencapai tujuan suatu organisasi yang sesuai dengan visi dan misi organisasi. Kepemimpinan kepala sekolah adalah sebuah 
kemampuan yang dimiliki oleh seorang tenaga fungsional guru yang mendapatkan tugas tambahan untuk memimpin sebuah sekolah untuk menggerakan berbagai sumber daya yang ada di sekolah agar dapat diberdayakan secara maksimal untuk mencapai tujuan yang telah ditetapkan (Rachmawati, 2013). Berbagai kebijakan berupa upaya untuk memastikan terjaminnya kelancaran PBM dengan melakukan proses penjaminan kesehatan guru dan siswa menunjukan bahwa kepala sekolah memiliki sikap adaptif dan siap untuk mengikuti perubahan. Ini adalah sikap kepemimpinan yang sangat dibutuhkan dalam kondisi pandemic seperti sekarang, sebagaimana dikatakan oleh Huntsman, dkk. (Huntsman et al., 2021) bahwa ketajaman untuk menangani kondisi kompleks, di mana perubahan konstan diperlukan.

Keterlibatan penulis selaku kepala madrasah dalam proses pembelajaran siswa lebih banyak dilakukan secara tidak langsung, yaitu melalui pembinaan terhadap para guru dan upaya penyediaan sarana belajar yang diperlukan. Penulis sebagai komunikator bertugas menjadi perantara untuk meneruskan instruksi kepada guru, serta menyalurkan aspirasi personel Madrasah kepada instansi kepada para guru, serta menyalurkan aspirasi personel madrasah kepada instansi vertikal maupun masyarakat. Pola komunikasi dari penulis pada umumnya bersifat kekeluargaan dengan memanfaatkan waktu senggang mereka. Alur penyampaian informasi berlangsung dua arah, yaitu komunikasi top-down, cenderung bersifat instruktif, sedangkan komunikasi bottom-up cenderung berisi pernyataan atau permintaan akan rincian tugas secara teknis operasional.

\section{Meningkatnya Kinerja Guru}

Gaya kepemimpinan open dan situasional yang diterapkan menghasilkan kesiapan dan kematangan dari para guru untuk menjalankan pekerjaan yang diberikan. Kesiapan dan kematangan tersebut diperoleh dari tingkat arahan dan bimbingan yang diberikan penulis serta dukungan emosional yang diberikan penulis kepada para guru. Terbentuknya kesiapan dan kematangan pada diri guru mampu menimbulkan suatu peningkatan kinerja. Hasil yang dicapai setelah dilaksanakan Gaya kepemimpinan open dan situasional di MA Darul Ma'arif Numbay, di uraikan :

1. Gaya telling (memberitahukan) dalam meningkatkan kinerja guru dapat dilihat bahwa selama ini penulis mampu memberikan instruksi kepada guru dalam pelaksanaan pembelajaran, sehingga hasilnya dapat dirasakan oleh siswa dalam proses pembelajaran baik dilakukan secara daring maupun tatap muka terbatas.

2. Gaya Selling/Menjajakan dalam Meningkatkan kinerja guru dimana selama ini penulis sebagai kepala madrasah aktif dalam memberikan semangat dan motivasi kepada guru dalam proses pembelajaran daring maupun tatap muka terbatas sehingga guru merasa nyaman dalam menjalankan tugasnya di madrasah.

3. Gaya Participating/Mengikutsertakan dimana selama masa pandemic penulis sebagai kepala madrasah mengikutsertakan para guru untuk aktif dalam berbagai kegiatan di lingkungan masyarakat, sehingga dengan kegiatan ini kami dapat langsung berkomunikasi dengan masyarakat dan dapat langsung menerima masukan dan saran yang diberikan oleh masyarakat terkait dengan kualitas dan mutu madrasah dimasa pandemic.

4. Gaya Delegating/Mendelegasikan dalam Meningkatkan kinerja guru selama ini penulis sering kali memberikan kesempatan kepada guru-guru untuk mewakili sekolah dalam berbagai kegiatan, hal ini dimaksudkan untuk meningkatkan kemampuan dan kompetensi yang dimiliki oleh guru.

Daryanto (2001) menyebutkan bahwa salah satu tantangan terberat bagi kepala sekolah pada masa pandemi Covid-19 adalah kewajiban untuk dapat harus menciptakan iklim pembelajaran yang kondusif. Kepala madrasah harus melibatkan bawahan (guru dan karyawan) dalam keikutsertaan dalam proses pengambilan keputusan menjalankan menejemen madrasah untuk menciptakan iklim pembelajaran yang kondusif pada masa Covid-19 


\section{Meningkatnya Pretasi Madrasah}

Di masa pandemic covid 19 perjalanan implementasi gaya kepemimpinan open dan situasional di MA Darul Ma'arif Numbay Jayapura terbukti memperoleh prestasi di antaranya :

1. MA Darul Ma'arif Numbay dapat meningkatkan nilai akreditasi di tahun 2020 dengan nilai dari 84 menjadi 87.

2. Siswa MA Darul Ma'arif Numbay memperoleh juara 2 di bidang fisika pada lomba KSMO tahun 2020 di tingkat Propinsi Papua

3. Siswa MA darul Ma'arif Numbay memperoleh juara 1 di bidang fisika pada lomba KSM tahun 2021 di tingkat Kota Jayapura.

4. Siswa MA Darul Ma'arif Numbay memperoleh juara III di bidang matematika pada lomba KSM tahun 2021 di tingkat kota Jayapura

5. Siswa MA Darul Ma'arif Numbay memperoleh juara III di bidang Fisika pada lomba KSM tahun 2021 di tingkat Propinsi Papua.

\section{KESIMPULAN}

Gaya kepemimpinan open dan situasional yang di terapkan kepala madrasah di MA Darul Ma'arif Numbay telling, selling, parcipating, delegating menunjukkan adanya peningkatan kinerja guru di masa pandemic covid 19. Selain kinerja guru yang meningkat juga terlihat adanya pestasi siswa yang ditunjukkan akibat dari penerapan gaya kepemimpinan open dan situasional walaupun tidak terlalu banyak namun hal ini menunjukkan bahwa gaya kepemimpinan open dan situasional dari kepala madrasah terlihat berhasil di terapkan di masa pandemic covid 19 di MA Darul Ma'arif Numbay.

\section{DAFTAR PUSTAKA}

Agustian, Rinto. (2016). Gaya Kepemimpinan Kepala Sekolah Dalam Meningkatkan Motivasi Kerja Guru. Jurnal Manajer Pendidikan Volume 10 Nomor 1.

E. Mulyasa. (2013). Manajemen dan Kepemimpinan Kepala Sekolah. Jakarta: PT. Bumi Aksara,

Hardavella, G., Aamli Gagnat, A., Xhamalaj, D., \& Saad, N. (2016). How to prepare for an interview. Breathe, 12(3), e86-e90. https://doi.org/10.1183/20734735.0137 16

Huntsman, D., Greer, A., Murphy, H., \& Haynes, S. (2021). Enhancing adaptive performance in emergency response: Empowerment practices and the moderating role of tempo balance. Safety Science, 134(December 2020), 105060. https://doi.org/10.1016/j.ssci.2020.105060

Mbogo, R. W. (2020). Leadership Roles in Managing Education in Crises: the Case of Kenya During Covid-19 Pandemic. European Journal of Education Studies, 7(9), 207-227. https://doi.org/10.46827/ejes.v7i9.3250

Rachmawati, Y. (2013). Pengaruh Kepemimpinan Kepala Sekolah Terhadap Kinerja Guru. Jurnal Pendidikan Ekonomi IKIP Veteran Semarang, 01, 19- 28

Sagala, H. Syaiful. (2018). Pendekatan dan Model Kepemimpinan edisi Pertama. Jakarta: Prenadamedia.

Yunidar. (2014). "Kepemimpinan Kepala Madrasah dalam Meningkatkan Kinerja Guru pada MAN Model Banda Aceh”, Didaktika, 324. 